\title{
ZASADA ZRÓWNOWAŻONEGO ROZWOJU A ZADANIA ADMINISTRACJI PUBLICZNEJ WOBEC OSÓB STARSZYCH Z PERSPEKTYWY NAUKI PRAWA ADMINISTRACYJNEGO. ZAGADNIENIA WYBRANE
}

\begin{abstract}
Streszczenie
Starzenie się polskiego społeczeństwa jest faktem. Możemy mu przeciwdziałać jedynie w ograniczonym zakresie. Należy go więc uwzględnić zarówno przy projektowaniu polityki państwa, jak i przy tworzeniu prawa administracyjnego $i$ wykonywaniu zadań administracji publicznej kierując się w tym zakresie zasada zrównoważonego rozwoju. Będzie wymagało to ważenia interesów ludzi młodych, $w$ wieku średnim $i$ starszych z uwzględnieniem zasady zrównoważonego rozwoju. Zrównoważony rozwój, w kontekście starzejącego się społeczeństwa, powinien zakładać takie kształtowanie procesów rozwojowych, które pozwola zachować równowage między potrzebami i aspiracjami ludzi należacymi do różnych grup wiekowych oraz potrzebami obecnych i przyszłych pokoleń. Zrównoważony rozwój dotyczy bowiem różnych aspektów funkcjonowania społeczeństwa i musi mieć charakter dtugoterminowy.
\end{abstract}

Słowa kluczowe: zrównoważony rozwój, starzenie się społeczeństwa, zadania administracji publicznej.

* Dr Agnieszka Piskorz-Ryń - doktor nauk prawnych, adiunkt w Katedrze Prawa Administracyjnego i Samorządu Terytorialnego WPiA UKSW. 


\section{Wprowadzenie}

Jednym z wyzwań przed jakimi stoją władze publiczne jest stale postępujący proces starzenia się obywateli. Ma on charakter stały i nieodwracalny, a jego stopień zaawansowania zależy od fazy rozwoju społeczeństwa1. Proces starzenia się społeczeństwa polskiego, tak jak i społeczeństw państw członkowskich Unii Europejskiej (UE), jest faktem ${ }^{2}$. Z tego względu problem ten powinien być analizowany z perspektywy różnych nauk społecznych, w tym nauki prawa administracyjnego. Wiadomo bowiem, że jest to zjawisko, z którym władze publiczne będą musiały się zmierzyć. $Z$ tego względu problem ten powinien być brany pod uwagę w różnych działaniach administracji publicznej, jak również uwzględniany w projektowaniu rozwiązań na przyszłość. Sposób podejścia do tego zagadnienia w działaniach administracji publicznej i przepisach prawa administracyjnego winna wyznaczać zasada zrównoważonego rozwoju.

Celem tego artykułu, jest przedstawienie problemu starzejącego się społeczeństwa z perspektywy tej zasady. Ze względu na ograniczone ramy tego opracowania zostanie ona omówiona w sposób syntetyczny i na tym tle przedstawione zostaną podstawowe wyzwania dla administracji publicznej. Ich zaprezentowanie będzie miało charakter ogólny, a ich katalog nie ma charakteru zamkniętego. Chodzi bowiem o pokazanie problemu, jego naszkicowanie, a nie dokonanie szczegółowego jego omówienia.

Przed przystąpieniem do przedstawienia zasady zrównoważonego rozwoju, konieczne jest jeszcze przyjęcie na potrzeby tego artykułu definicji „starzenia się”, używanej w kontekście społeczeństwa. Oznacza zwiększanie w społeczeństwie liczby osób starszych przy jednoczesnym zmniejszaniu liczby dzieci. W literaturze jako metrykalny próg starości przyjmuje się najczęściej 60 lat (Światowa Organizacja Zdrowia) lub 65 lat (Organizacja Narodów Zjednoczonych, Eurostat). Istnieje wiele miar i klasyfikacji stopnia zaawansowania starzenia się społeczeństwa. Zgodnie z kryterium ONZ - za starą uznaje się populację, w której udział ludności w wieku 65 lat i więcej przekracza 7\%33.

1 Prognoza ludności na lata 2014-2050, Główny Urząd Statystyczny, Warszawa 2014, s. 124.

2 Prognoza ludności na lata 2014-2050, tamże, s. 109 i n.

3 Prognoza ludności na lata 2014-2050, tamże, s. 126. 


\section{Zasada zrównoważonego rozwoju}

Zasada zrównoważonego rozwoju pojawiła się w latach 70. XX wieku w dyskusjach nad przyszłością świata prowadzonych w ramach ONZ. Była ona przedmiotem zainteresowania Komisji ds. Środowiska i Rozwoju utworzonej w 1983 r. przez Zgromadzenie Ogólne ONZ, w skład której wchodzili politycy, naukowcy i przedstawiciele organizacji pozarządowych. Efektem jej prac był raport pt. „Nasza wspólna przyszłość" przyjęty w 1987 r. przez 42. Sesję Zgromadzenia Ogólnego ONZ, w którym wskazano: „Trwały rozwój służy zaspokojeniu potrzeb bieżących bez ponoszenia ryzyka, że przyszłe pokolenia nie będą mogły zaspokoić swoich potrzeb"4. Problematykę tą poruszano również w dokumencie „Agenda 21: program działań na rzecz zrównoważonego rozwoju"s. Pisano w nim o nowym etapie rozwoju ludzkości, nowej filozofii życia i nowym typie cywilizacji postindustrialnej, którą nazwano cywilizacją zrównoważonego rozwoju. Zaznaczając, że wymaga integracji trzech filarów: gospodarczego, społecznego i środowiskowego.

Obecnie zrównoważony rozwój jest przedmiotem niesłabnącego zainteresowania. Ujmuje się go szerzej i jest odnoszony nie tylko do kwestii ochrony środowiska. Wiąże się go z jakością życia wspólnoty na poziomie lokalnym, państwowym i międzynarodowym. Celem, do którego współcześnie się dąży, jest nadal rozwój, ale jego realizacja odbywa się na innych niż dotychczas zasadach. Powinien uwzględniać istnienie granic naturalnych, społecznych i systemowych. Polega również na pozytywnych zmianach, podejmowanych tak, aby nie naruszały systemów środowiskowych i społecznych, w których funkcjonujemy i od których jesteśmy zależni. Wymaga również aktywnego udziału społeczeństwa w tych zmianach.

Zrównoważony rozwój uznaje się za najważniejszą z perspektywy przyszłości zasadę europejskiej myśli konstytucyjnej ${ }^{6}$. Jest ona wyrażona w Konstytucji Rzeczypospolitej Polskiej z 2 kwietnia 1997 r. ${ }^{7} \mathrm{~W}$ art. 5 zapisano: „Rzeczpospolita Polska strzeże niepodległości i nienaruszalności swojego terytorium, zapewnia wolności i prawa człowieka i obywatela oraz bezpieczeństwo obywateli, strzeże dziedzictwa narodowego oraz zapewnia ochronę środowiska, kierując się zasadą zrównoważonego rozwoju". Przepis ten jest źródłem wątpliwości interpretacyjnych. Dotyczą one przede wszystkim zakresu jej stosowania. Brak zgodności

\footnotetext{
4 Zob. Nasza wspólna przyszłość - Raport Brundtland WC EDOCF, New York 1987.

5 Dokument ten został przyjęty na kongresie ONZ w Rio de Janeiro w 1992 roku, zwanym Szczytem Ziemi.

6 A. Jakab, Sunstainbility in European Constitutional Law, w: Social Science Research Network (SSRN), http://papers.ssrn.com/sol3/Papers.cfm?abstract_id=2593371.

7 Dz.U. nr 78, poz. 483 ze zm.
} 
w piśmiennictwie, co do tego, czy Rzeczpospolita Polska urzeczywistnia wszystkie wartości w nim wskazane, kierując się zasadą zrównoważonego rozwoju czy też odnosi się ona wyłącznie do ochrony środowiska.

Za wąskim rozumieniem tej zasady opowiada się B. Banaszak. W jego ocenie: „Zasada zrównoważonego rozwoju, którą ma się kierować Rzeczpospolita, zapewniając ochronę środowiska, jest w języku prawnym stosunkowo nowym pojęciem ukształtowanym na początku lat 90. XX w. Oznacza ona konieczność znajdowania takich rozwiązań technicznych, organizacyjnych, prawnych itp. sprzyjających rozwojowi ekonomicznemu, czy szerzej, cywilizacyjnemu, które pozwolą chronić środowisko naturalne" ${ }^{8}$. Inaczej do kwestii tej odnosi się A. Bałaban, który wskazuje, że „można traktować ją jako samoistną wartość mogącą mieć odniesienie do innych postanowień konstytucji i przydatność do konstruowania jej norm w zestawieniu z treścią innych przepisów, co jest cechą wszystkich wartości zawartych w art. 5"9. Podkreśla również, że „,nadmiernym zawężeniem treści zasady zrównoważonego rozwoju byłoby jej wyłączne traktowanie jako metody ochrony środowiska naturalnego, gdyż treściowa pojemność tej «metody» przerasta znacznie problematykę ochrony środowiska - tradycyjnie rozumianego" ${ }^{10}$. Podobny pogląd wyraża W. Skrzydło, który zauważa, że: „Art. 5 określa funkcje państwa, czyli zasadnicze kierunki i cele jego działania. (...) Kluczową funkcją jest niewątpliwie strzeżenie niepodległości i nienaruszalności terytorium Rzeczypospolitej, gdyż jej realizacja pozwala na wykonywanie takich funkcji, jak: zapewnienie wolności i praw człowieka i obywatela, jak też jego bezpieczeństwa, ochrona dziedzictwa narodowego, a także ochrona środowiska. U podstaw realizacji tych funkcji leży zasada zrównoważonego rozwoju państwa" "11. Za szerokim rozumieniem art. 5 Konstytucji opowiada się B. Rakoczy ${ }^{12}$ zdaniem, którego na taką interpretację wskazuje użycie przez ustawodawcę przecinka, po określeniu obowiązku zapewnienia ochrony środowiska. Podobnie M. Stoczkiewicz, który zauważa, że „można (...) sformułować zasadę zrównoważonego rozwoju jako normę nakazującą

8 Zob. B. Banaszak, Konstytucja Rzeczypospolitej Polskiej. Komentarz, CH Beck, Warszawa 2012, s. 74.

9 Zob. A Bałaban, Konstytucyjna zasada zrównoważonego rozwoju, w: Sześć lat Konstytucji Rzeczypospolitej Polskiej. Doświadczenia i inspiracje, red. L. Garlicki, A. Szmyt, Wydawnictwo Sejmowe, Warszawa 2003, s. 21.

10 A. Bałaban, Konstytucyjna zasada zrównoważonego rozwoju, tamże, s. 20.

11 W. Skrzydło, Komentarz do art. 5 Konstytucji Rzeczypospolitej Polskiej, w: Konstytucja Rzeczypospolitej Polskiej. Komentarz, Wolters Kluwer, Warszawa, 2013.

12 B. Rakoczy, Komentarz do Konstytucji Rzeczypospolitej Polskiej, w: Prawo ochrony środowiska. Komentarz, LexisNexis, Legalis'el, Warszawa 2013. 
wszystkim organom państwa abstrakcyjnie, tj. zawsze, i we wszystkich ich działaniach dążyć do osiągnięcia stanu zrównoważonego rozwoju. Art. 5 [Konstytucji] in fine nakazuje bowiem przestrzeganie zasady zrównoważonego rozwoju, a zasada ta (...) nakazuje dążenie do osiągnięcia stanu zrównoważonego rozwoju"13.

Jak wskazano, w doktrynie przeważają opinie dotyczące szerokiego rozumienia tej zasady na gruncie Konstytucji RP. Trybunał Konstytucyjny stwierdził, że „w ramach zasady zrównoważonego rozwoju mieści się nie tylko ochrona przyrody, czy kształtowanie ładu przestrzennego, ale także należyta troska o rozwój społeczny i cywilizacyjny, związany z koniecznością budowania stosownej infrastruktury niezbędnej dla rozwoju - uwzględniającego cywilizacyjne potrzeby - życia człowieka i poszczególnych wspólnot. Idea zrównoważonego rozwoju zawiera więc w sobie potrzebę uwzględnienia różnych wartości konstytucyjnych i stosownego ich wyważenia"'14.

Nowoczesna administracja publiczna, skierowana ku przyszłości, powinna brać pod uwagę zasadę zrównoważonego rozwoju w każdym aspekcie swojej działalności. Winna mieć ona szczególne znaczenie, również przy tworzeniu regulującego zasady jej funkcjonowania prawa administracyjnego. Działania podejmowane przez społeczeństwo w XXI wieku powinny być nakierowane na zrównoważony rozwój w każdej sferze życia, co musi znaleźć odzwierciedlenie również $\mathrm{w}$ prawie administracyjnym ${ }^{15}$. Przy jego tworzeniu należy dostrzegać nie tylko aktualne problemy społeczne, ale i przyszłe potrzeby ludzkości. Z tego względu przez część przedstawicieli doktryny uznaje się zasadę zrównoważonego rozwoju za jedną z zasad prawa administracyjnego. J. Zimmermann podkreśla, że „zrównoważony rozwój powinien polegać na takim prowadzeniu wszelkich procesów rozwojowych, żeby zachować równowagę między regionami, między ludzkimi potrzebami a aspiracjami ludzi oraz między podejmowanymi inwestycjami a ograniczeniami, jakie mogą one spowodować, między potrzebami następnych pokoleń" ${ }^{16}$. Wskazuje się również, iż „zasada zrównoważonego rozwoju jest zasadą, która znajduje nie tylko zastosowanie na gruncie tworzenia prawa, w tym

13 M. Stoczkiewicz, Zasada zrównoważonego rozwoju jako zasada prawa, „Prawo i Środowisko" 2001, nr 1, s. 125.

14 Zob. wyrok TK z dnia 6 czerwca 2006 r., sygn. akt K23/05 OTK 2006, nr 6, seria A, poz. 62.

15 A. Piskorz-Ryń, J. Wyporska-Frankiewicz, Zasada zrównoważonego rozwoju z perspektywy prawa administracyjnego. Zagadnienia wybrane, w: Społeczna odpowiedzialność jako podstawa osiagania zrównoważonego rozwoju, red. O. Kotowska-Wojcik, M. Luty-Michalak, Wydawnictwo UKSW, Warszawa 2016, s. 67.

16 J. Zimmermann, Prawo administracyjne, Zakamycze, Kraków, 2014, s. 132. 
prawa administracyjnego, będąc wzorcem dla jego konstytucyjności, ale jest także zasadą znajdującą zastosowanie podczas konkretyzacji prawa administracyjnego, która musi kierować się ideą zrównoważonego rozwoju."”. Tym samym zasada ta powinna być wypełniana treścią zarówno w procesie stanowienia, jak i stosowania prawa, zwłaszcza prawa administracyjnego ${ }^{18}$. Zrównoważony rozwój powinien więc zakładać zgodę, współpracę i współdziałanie organów władzy publicznej przy urzeczywistnianiu określonych wartości i interesów, a także takie ich wyważenie, by spełnione zostały standardy demokratycznego państwa prawnego ${ }^{19}$. G. Szpor, która uznając zasadę zrównoważonego rozwoju za zasadę ogólną prawa ochrony środowiska, prawa zagospodarowania przestrzennego, a także prawa samorządowego - wskazuje, że „zasada zrównoważonego rozwoju jako ogólna zasada prawa wyznacza relacje między chronionymi już wcześniej wartościami: sprawiedliwością społeczną, wolnością gospodarczą i przezornością w korzystaniu ze środowiska, odnoszona będzie także do innych dyscyplin szczegółowych, gałęzi, działań, a nawet całego systemu prawa, bowiem nawiązuje do niej coraz więcej aktów normatywnych"20.

Społeczeństwo XXI wieku musi być nakierowane na zrównoważony rozwój, w każdym aspekcie życia, a na straży takiego rozwoju stać winna administracja publiczna. To ona bowiem jest powołana do zawiadywania sprawami publicznymi oraz dbania o dobro wspólne, uwzględniając przy tym nie tylko interesy obecnych, ale i przyszłych pokoleń ${ }^{21}$. Potencjał zasady zrównoważonego rozwoju należy więc wykorzystać również na gruncie prawa administracyjnego. Posłużenie się w art. 5 Konstytucji RP pojęciem zrównoważonego rozwoju należy traktować jako wyraz woli prawodawcy konstytucyjnego, aby była ona realizowana w całym systemie prawa, a więc również w sferze prawa administracyjnego. Ma ona bowiem charakter porządkujący, a jej istotą jest uwzględnianie i ważenie różnych

17 I. Skrzydło-Niżnik, P. Dobosz, Pojęcie zrównoważonego rozwoju w systemie prawa $i$ nauce prawa administracyjnego, w: Jednostka $w$ demokratycznym państwie prawa, red. J. Filipek, Wydawnictwo WSA, Bielsko-Biała 2003, s. 626.

18 J. Zimmermann, Prawo administracyjne, tamże, s. 132-133.

19 A. Syryt, Dostęp do publicznych zasobów informacyjnych a zasada zrównoważonego rozwoju, w: Jawność i jej ograniczenia, t. V, Dostęp i wykorzystywanie, red. A. PiskorzRyń, CH Beck, Warszawa 2015, s. 33.

20 G. Szpor, Zasada zrównoważonego rozwoju jako zagadnienie prawne, w: Zarzadzanie informacja przestrzenna w nowym tysiacleciu, Stowarzyszenie SILGIS Center, Katowice 1999, s. 486.

${ }^{21}$ A. Piskorz-Ryń, J. Wyporska-Frankiewicz, Zasada zrównoważonego rozwoju z perspektywy prawa administracyjnego, tamże, s. 79. 
interesów w różnych obszarach życia, w tym przede wszystkim normowanych prawem administracyjnym.

\section{Zadania administracji publicznej wobec osób starszych z perspektywy zasady zrównoważonego rozwoju}

Analizę zadań administracji publicznej w związku ze starzeniem się społeczeństwa, rozpocząć należy od bardzo ogólnego przedstawienia tego procesu. Można wskazać na trzy grupy problemów. Do pierwszej zaliczyć należy brak prostej zastępowalności pokoleń. Przez pojęcie to należy rozumieć sytuację, w której liczba narodzin jest większa niż liczba zgonów. Druga, związana jest ze wzrostem średniej wieku populacji, co wiąże się ze zmianą struktury społeczeństwa. Zgodnie z przyjętymi założeniami w Polsce w 2050 r. mężczyźni, przy niezmienionych warunkach wymierania ludności, będą żyli przeciętnie - według wariantu najmniej optymistycznego „niskiego” - 81,5 lata, natomiast kobiety 87,6 lat. Według wariantu najbardziej optymistycznego - przewiduje się dla mężczyzn średni wiek życia 84,1 lat, natomiast dla kobiet blisko 89 lat. Na tle ogólnej tendencji malejącego natężenia zgonów zmniejszy się nadumieralność mężczyzn, a tym samym rozpiętość między przeciętnym trwaniem życia mężczyzn i kobiet zmaleje ${ }^{22}$. Wszystkie scenariusze przewidują, że do 2050 r. odsetek ludności w wieku 65 lat i więcej wzrośnie około dwukrotnie tj. z 15,8\% w 2013 r. do 35,7\% w scenariuszu „niskim”, zaś do 31,3\% w scenariuszu „,bardzo wysokim”23. Jednocześnie we wszystkich wariantach do 2050 r. odsetek ludności w wieku 0-14 lat zmaleje z 15\% jaki był w 2013 r. do $14,2 \%$ w scenariuszu bardzo wysokim, zaś do 11,3\% w scenariuszu „niskim”. Trzecia grupa, związana jest ze wzrostem liczby sędziwych starców, przez co rozumie się osoby powyżej osiemdziesiątego roku życia. Ich liczba w państwach członkowskich UE wzrosła między rokiem 2005 a 2010 o 17,1 \%, a między 2010 r a 2030 r. wrośnie o $57,1 \%{ }^{24}$.

W związku z tym zadania administracji publicznej związanej ze starzejącym się społeczeństwem można podzielić umownie na pięć kategorii. Obejmują one zarówno obecne zadania administracji publicznej, jak i te które na podstawie prawa powinna wykonywać w przyszłości. Rolą prawa administracyjnego i administracji publicznej jest podejmowanie działań związanych z:

22 Prognoza ludności na lata 2014-2050, tamże, s. 76.

23 Prognoza ludności na lata 2014-2050, tamże, s. 159.

24 Komunikat Komisji z 16.3.2005 COM (2005) 94, Zielona Księga „Wobec zmian demograficznych: nowa solidarność między pokoleniami”, s. 8. 
1. wzrostem dzietności (kategoria ta obejmuje działania bezpośrednio lub pośrednio nakierowane na promowanie rodzicielstwa),

2. aktywnym starzeniem się i jak najdłuższym uczestniczeniem osób starszych w rynku pracy,

3. zapewnieniem lepszej jakości życia osób starszych, wraz z umożliwieniem ich partycypacji w życiu społecznym,

4. opieką medyczną seniorów, tak by jak najdłużej pozostawali aktywnymi członkami społeczeństwa oraz zapewnieniem im zabezpieczenia społecznego na należytym poziomie,

5. pomocą socjalną, przeciwdziałaniem ubóstwu i opieką nad osobami zależnymi, w tym przede wszystkim sędziwymi starcami.

Opisywane zadania wiążą się bezpośrednio z innymi wyzwaniami, jakie stoją przed rządami krajowymi i Unią Europejską. Dotyczą one zapewnienia konkurencyjności gospodarki, proaktywnej polityki imigracyjnej dostosowanej do potrzeb demograficznych oraz wyzwań rynku pracy, jak również działaniami związanymi ze wzrostem liczby kobiet aktywnych zawodowo ${ }^{25}$. Bez kompleksowych działań systemowych nie będzie możliwe bowiem sprostanie starzejących się społeczeństw stale zwiększającym się nakładom na opiekę zdrowotną, socjalną oraz zabezpieczenie społeczne. Kwestie te ze względu na ich zakres nie będą w artykule omawiane.

Przedstawiona powyżej lista zadań administracji publicznej związanych ze starzeniem się społeczeństwa, pomimo jej ogólnego charakteru, jest bardzo rozbudowana. Ich wykonanie będzie również związane z ogromnymi nakładami publicznymi. Będzie wymagało ważenia interesów ludzi młodych, w wieku średnim i starszych z uwzględnieniem zasady zrównoważonego rozwoju. Zrównoważony rozwój, w kontekście starzejącego się społeczeństwa, powinien zakładać takie kształtowanie procesów rozwojowych, które pozwolą zachować równowagę między potrzebami i aspiracjami ludzi należącymi do różnych grup wiekowych oraz potrzebami obecnych i przyszłych pokoleń. Realizując zasadę zrównoważonego rozwoju należy podejmować działania dla stworzenia społeczeństwa dla wszystkich generacji, uwzględniającego jednocześnie potrzeby osób starszych, których liczba stale będzie wzrastać, jak i osób młodych, i w wieku średnim. Zrównoważony rozwój, sięgający swymi korzeniami problemów środowiskowych, wymaga obecnie odpowiedzialności nie tylko przed tymi, którzy przyjdą po nas i odpowiedzialności za środowisko jakie im zostawimy. Wymaga także odpowiedzialności wobec tych pokoleń, z którymi przyjdzie nam żyć. $Z$ tego względu konieczne jest

25 Projekt Europa 2030. Wyzwania i szanse. Sprawozdanie dla Rady Europejskiej, sporządzone przez Grupę Refleksji dotyczące przyszłości UE do roku 2030, maj 2010, s. 6. Szerzej na temat polityki imigracyjnej, tamże, s. 26 i n. 
uwzględnianie w zrównoważonym rozwoju, poza aspektem środowiskowym, również aspektu społecznego. Jego kwintesencją powinna być równowaga międzypokoleniowa. Powinna uwzględniać godzenie różnych interesów pokoleniowych. Należy kształtować ją przy świadomości zmian demograficznych. Dążenie do jej zachowania nie może być postrzegane jedynie w aspekcie finansowym. Ten, jednak jest bardzo istotny. Starzenie się społeczeństwa generuje nakłady publiczne związane z finansowaniem świadczeń emerytalnych, czy zapewnieniem ochrony zdrowia starszym członkom społeczeństwa. $Z$ tego względu zrównoważony rozwój wymaga pewnych ograniczeń, już teraz dla zabezpieczenia interesów, może nie tyle przyszłych pokoleń, które przyjdą po nas, co młodszych członków społeczeństwa. Dotyczy to, przede wszystkim oczekiwań dotyczących skrócenia wieku emerytalnego. Można więc wskazać na dwa filary solidarności międzypokoleniowej z perspektywy zrównoważonego rozwoju, jest nim odpowiedzialność międzypokoleniowa i godność człowieka. Zrównoważony rozwój dotyczy różnych aspektów funkcjonowania społeczeństwa i musi mieć charakter długoterminowy. Powinien zakładać zgodę, współpracę i współdziałanie organów władzy publicznej przy urzeczywistnianiu określonych wartości i interesów, a także takie ich wyważenie, by spełnione zostały standardy demokratycznego państwa prawnego ${ }^{26}$. Zarówno przy podejmowaniu rozstrzygnięć legislacyjnych, jak i wykonywaniu zadań administracji publicznej, dotyczących interesów poszczególnych grup pokoleniowych ważnym jest, by interes jednej grupy nie zostawał uwzględniany z pominięciem analizy pozostałych.

Zgodnie z zasadą zrównoważonego rozwoju minimalizować należy ryzyko, wyraźnego prymatu jednych interesów kosztem drugich. Każdorazowo należy dokonać rachunku korzyści i strat, tak aby w konkretnym wypadku, najlepiej zrealizować ustalony cel. Decyzje w tych sprawach powinny być podejmowane świadomie, przy zastosowaniu ewentualnych mechanizmów ochronnych, dla tych których interesy będą „,poświęcone”. Poszukiwać należy takich gwarancji/mechanizmów/rozwiązań, które łagodziłyby konsekwencje „gorszego” potraktowania innych interesów. Kierowanie się zrównoważonym rozwojem, w tym wypadku polega na tym, że władza publiczna powinna starać się pogodzić wartości i interesy, które wpływają na kształt społeczeństwa i demokratycznego państwa prawnego, jako całości z jego elementami gospodarczymi, społecznymi, środowiskowymi, czy ustrojowymi ${ }^{27}$. Powinna również dążyć do zapewnienia partycypacji w życiu

26 A. Syryt, Dostęp do publicznych zasobów informacyjnych a zasada zrównoważonego rozwoju, w: Jawność i jej ograniczenia, tamże, s. 33.

27 A. Syryt, Dostęp do publicznych zasobów informacyjnych a zasada zrównoważonego rozwoju, tamże, s. 33. 
publicznym. Ważnym jest więc zapewnienie należytego poziomu tej partycypacji niezależnie od grupy wiekowej ${ }^{28}$. Tylko bowiem właściwe zdiagnozowanie potrzeb społecznych daje możliwość ich uwzględnienia. Z tego względu przeciwdziałać należy wykluczeniu, pewnych grup interesariuszy w procesach decyzyjnych. Dotyczy to przede wszystkim ludzi starszych i chorych. Odpowiedzią na tą potrzebę jest tworzenie m.in. rad seniorów przewidzianych w ustawie o samorządzie gminnym ${ }^{29}$. Nowelizacja tej ustawy motywowana była potrzebą aktywizacji obywatelskiej osób starszych do podejmowania dialogu społecznego w miejscu zamieszkania ${ }^{30}$.

Biorąc pod uwagę powyższe, administracja publiczna i regulujące jej działania prawo administracyjne, powinno dążyć do zapewnienia solidarności międzypokoleniowej. Zapewnienie tej solidarności jest jednym z zadań UE ${ }^{31}$. Definiując solidarność międzypokoleniową sprecyzować należy rozumienie poszczególnych członów tego pojęcia. Pojęcie solidarności oznacza,„życzliwość, gotowość do współpracy, poparcia i niesienia pomocy wobec osób, które obejmujemy kategorią „my”: członków naszej grupy, czy kategorii społecznej oraz solidarność globalną wyrażające się m.in. w idei uniwersalnych praw człowieka, ruchu ekologicznym, czy pokojowym, kampaniach pomocy międzynarodowej dla ofiar katastrof, czy klęsk żywiołowych - poczucie wspólnoty wykraczające poza obszar jednego narodu bądź państwa"32. Słowo zaś pokolenie, jak wskazuje P. Szukalski, można definiować w trzech kontekstach ${ }^{33}$. Zgodnie z pierwszym, przez pokolenie $\mathrm{w}$ antropologii rozumie się ogół spokrewnionych osób, posiadających wspólnego przodka. Drugie, bliższe analizom demograficznym i ekonomicznym - przez pokolenie rozumie grupę osób w zbliżonym wieku - urodzonych w tym samym okresie, $\mathrm{z}$ reguły analizowanym z punktu widzenia roku lub lat pięciu. W przypadku podejścia ekonomicznego często uwzględnia się (potencjalną) aktywność zawodową,

28 Na temat znaczenia partycypacji interesariuszy w procesach decyzyjnych zob. A. Jawor-Joniewicz, J. Kornecki, J. Wiktorowicz, Katalog dobrych praktyk $w$ zakresie aktywnego starzenia się w wybranych krajach Unii Europejskiej. Studia przypadku, Łódź 2013, passim.

29 Zostały one wprowadzone ustawą z 21 października 2013 r. o zmianie ustawy o samorządzie gminnym (Dz.U. 2013, poz. 1318).

30 R. Mędrzycki, Funkcje gminnych rad seniorów, „Ruch Prawniczy Ekonomiczny i Socjologiczny" 2017, nr 3, s. 119.

31 Art. 3 Traktatu o Unii Europejskiej i Traktatu o funkcjonowaniu Unii Europejskiej w wersji skonsolidowanej opublikowanego w Dz.Urz.UE 2016 C 202, s.1.

32 P. Sztompka, Socjologia. Analiza społeczeństwa, Znak 2002, s. 197.

33 P. Szukalski, Czym jest solidarność międzypokoleniowa, w: Jakość życia seniorów XXI wieku z perspektywy polityki społecznej, red. D. Kałuża, P. Szukalski, Łódź, Wydawnictwo Biblioteka, s. 76-77. 
wyodrębniając osoby w wieku przedprodukcyjnym, produkcyjnym i poprodukcyjnym. Użycie słowa „potencjalną” ma podkreślić umowność tej kategorii, albowiem w rzeczywistości kryterium jest ponownie wiek. Trzecie podejście - typowe dla polityki społecznej - pozwala na wyodrębnienie docelowych grup owej polityki, tj. osób w zbliżonym wieku, posiadających podobne potrzeby i posiadających takie same uprawnienia do rożnego typu świadczeń społecznych ${ }^{34}$. W podejmowanych rozważaniach pokolenie może być rozumiane w różnym ze wskazanych znaczeń. Wydaje się jednak, że przede wszystkim trzeba rozumieć je w opisywanym kontekście, jako grupę osób o zbliżonym wieku, mających podobne problemy i potrzeby. Tam zaś, gdzie mowa jest o pokoleniu w pierwszym rozumieniu, dla potrzeb prawa administracyjnego lepiej używać pojęcia rodziny.

Solidarność międzypokoleniowa, może być definiowana również jako więź nie tylko społeczna, ale i prawna, odnoszona do relacji pomiędzy: a) współwystępującymi (współegzystującymi) w jednym czasie pokoleniami, b) pokoleniem współczesnym przy uwzględnieniu dorobku pokoleń antenackich (ascendentnych) generacji współczesnej - pokoleń minionych (tych, których już nie ma), lub/i uzasadnionych prawnie oczekiwań pokoleń przyszłych, jeszcze nienarodzonych (tych których jeszcze nie ma), czyli pokoleń descendentnych ${ }^{35}$. Takie definiowanie solidarności międzypokoleniowej pokazuje jej bezpośredni związek z zasadą zrównoważonego rozwoju mając wobec tej zasady charakter uzupełniający.

Ową solidarność traktować należy jako pewien postulat odzwierciedlany w życiu społecznym, który należy realizować na różnych poziomach funkcjonowania państwa. Jest to zarówno postulat dotyczący prowadzenia polityki społecznej, kształtowania rozwoju społecznego, ale również tworzenia rozwiązań prawnych w zakresie prawa administracyjnego, zarówno materialnego, jak i ustrojowego.

Zielona Księga „Wobec zmian demograficznych: nowa solidarność między pokoleniami" wskazuje na konieczność rozwinięcia nowego rodzaju solidarności międzypokoleniowej, opartej na wzajemnym wspieraniu, przekazywaniu wiedzy $\mathrm{i}$ doświadczeń ${ }^{36}$. Jest to przede wszystkim związane z rynkiem pracy, na którym coraz dłużej będą pozostawać starsi pracownicy. Należy zapewnić jednocześnie młodym możliwość znalezienia swojego miejsca na rynku pracy, wraz z możliwoś-

34 P. Szukalski, Czym jest solidarność międzypokoleniowa, tamże s. 76-77.

35 P. Dobosz, Prawnicza egzemplifikacja sprawiedliwości międzypokoleniowej z wykorzystaniem zróżnicowanych składników siatki pojęciowej wybranego ustawodawstwa prawa administracyjnego, w: Sprawiedliwość i zaufanie do władz publicznych w prawie administracyjnym, red. M. Kasiński, M. Sthal, K. Wlaźlak, LEX, el.

${ }^{36}$ Zielona Księga ,Wobec zmian demograficznych: nowa solidarność między pokoleniami”, tamże, s. 7. 
cią awansu zawodowego. Ludzie młodzi są i będą coraz lepiej wykształceni. Należy zapewnić im możliwość kariery zawodowej, przy jednoczesnym korzystaniu z doświadczenia i wiedzy osób starszych. Konieczne jest również wspieranie pozostania osób starszych na tym rynku, wraz z stworzeniem możliwości pracy w ograniczonym wymiarze czasu pracy, czy takiej organizacji, która odpowiada potrzebom osób starszych. Będzie to wymagało przeorganizowania zasad pracy, wraz z projektowaniem innych ścieżek kariery zawodowej uwzględniających z jednej strony opiekę nad dziećmi, jak i sędziwymi starcami, których liczba będzie wzrastać.

Zadaniem administracji będzie przeorganizowanie opieki nad osobami w podeszłym wieku (powyżej 80 lat). Rodziny nie będą w stanie same rozwiązać tego problemu. Niezależnie od tego, czy osoby te będą samodzielne i będą pragnęły mieszkać w swoim domu, czy też dotyczyć to będzie opieki ,intensywnej” na końcowym etapie życia człowieka. Istotną w tym zakresie rolę będą odgrywały gminy, które powinny zapewnić pomoc i wsparcie w opiece nad tymi osobami. Wiązać się to będzie również z tym, że w dużej części osoby te będą utrzymywały się wyłącznie lub prawie wyłącznie ze świadczeń emerytalnych ${ }^{37}$. Należy różnicować więc zakres pomocy i sposób jej organizacji. Jednym więc z pytań na jakie należy odpowiedzieć, jest następujące: jak w sposób zrównoważony rozdzielić opiekę nad ludźmi starymi między rodziny, służby socjalne i instytucje? ${ }^{38}$. Bezsprzecznie konieczne będzie podjęcie działań wspierających rodzinę w pełnieniu przez nią funkcji opiekuńczych w stosunku do osób niesamodzielnych. Rodzina powinna być traktowana jako najważniejszy partner w sprawowaniu opieki, objęty wszechstronnym wsparciem i mający prawo do świadczeń socjalnych. Budowanie systemu opieki, o ile to możliwe, powinno odbywać się z uwzględnieniem solidarności międzypokoleniowej.

\section{Podsumowanie}

Starzenie się polskiego społeczeństwa jest faktem. Możemy mu przeciwdziałać jedynie w ograniczonym zakresie. Należy go więc uwzględnić zarówno przy projektowaniu polityki państwa, jak również przy tworzeniu prawa administracyjnego i w wykonywaniu zadań administracji publicznej. Przyjmując za I. Lipowicz, że administracja publiczna to ,system złożony z ludzi zorganizowany w celu stałej,

37 P. Błędowski, Opieka dtugoterminowa w Polsce wobec starzenia się ludności, w: Starzenie się ludności, rynek pracy i finanse publiczne w Polsce, red. P. Lewandowski, J. Rutkowski, Przedstawicielstwo Komisji Europejskiej w Polsce 2017, s. 42.

38 Zielona Księga, tamże, s. 10. 
systematycznej, skierowanej ku przyszłości realizacji dobra wspólnego jako misji publicznej, polegającej głównie (choć nie wyłącznie) na bieżącym wykonywaniu ustaw, wyposażonych w tym celu we władztwo państwowe oraz środki materialno-techniczne" 39 . Powinna ona więc w swych działaniach uwzględniać sytuację obecną, jak i przyszłe problemy związane z koniecznością tworzenia „społeczeństwa dla wszystkich generacji” (ang. socjety for all ages). Wydaje się, że bardzo pomocna w podejściu do tego problemu jest zasada zrównoważonego rozwoju, która koresponduje z postulatem solidarności międzypokoleniowej.

\section{Bibliografia}

Banaszak B., Konstytucja Rzeczypospolitej Polskiej. Komentarz, CH Beck, Warszawa 2012.

Bałaban A., Konstytucyjna zasada zrównoważonego rozwoju, w: Sześć lat Konstytucji Rzeczypospolitej Polskiej. Doświadczenia i inspiracje, red. L. Garlicki, A. Szmyt, Wydawnictwo Sejmowe, Warszawa 2003.

Błędowski P., Opieka dtugoterminowa w Polsce wobec starzenia się ludności, w: Starzenie się ludności, rynek pracy i finanse publiczne w Polsce, red. P. Lewandowski, J. Rutkowski, Przedstawicielstwo Komisji Europejskiej w Polsce 2017.

Dobosz P., Prawnicza egzemplifikacja sprawiedliwości międzypokoleniowej $z$ wykorzystaniem zróżnicowanych składników siatki pojęciowej wybranego ustawodawstwa prawa administracyjnego, w: Sprawiedliwość i zaufanie do władz publicznych $w$ prawie administracyjnym, red. M. Kasiński, M. Sthal, K. Wlaźlak, LEX, el.

Jakab A., Sunstainbility in European Constitutional Law, w: Social Science Research Network (SSRN), http://papers.ssrn.com/sol3/Papers.cfm?abstract_id=2593371.

Jawor-Joniewicz A., Kornecki J., Wiktorowicz J., Katalog dobrych praktyk w zakresie aktywnego starzenia się w wybranych krajach Unii Europejskiej. Studia przypadku, Łódź 2013.

Mędrzycki R., Funkcje gminnych rad seniorów, „Ruch Prawniczy Ekonomiczny i Socjologiczny" 2017, nr 3.

Nasza wspólna przyszłość - Raport Brundtland WC EDOCF, New York 1987.

Piskorz-Ryń A., Wyporska-Frankiewicz J., Zasada zrównoważonego rozwoju z perspektywy prawa administracyjnego. Zagadnienia wybrane, w: Społeczna odpowiedzialność jako podstawa osiagania zrównoważonego rozwoju, red.

39 I. Lipowicz, Istota administracji, w: Prawo administracyjne, red. Z. Niewiadomski, Warszawa 2005, s. 28. 
O. Kotowska-Wojcik, M. Luty-Michalak, Wydawnictwo UKSW, Warszawa 2016.

Projekt Europa 2030. Wyzwania i szanse. Sprawozdanie dla Rady Europejskiej, sporzadzone przez Grupę Refleksji dotyczace przyszłości UE do roku 2030, maj 2010.

Prognoza ludności na lata 2014-2050, Główny Urząd Statystyczny, Warszawa 2014. Rakoczy B., Komentarz do Konstytucji Rzeczypospolitej Polskiej, w: Prawo ochrony środowiska. Komentarz, LexisNexis, Warszawa 2013, Legalis'el.

Stoczkiewicz M., Zasada zrównoważonego rozwoju jako zasada prawa, „Prawo i Środowisko" 2001, nr 1.

Skrzydło W., Komentarz do art. 5 Konstytucji Rzeczypospolitej Polskiej, w: Konstytucja Rzeczypospolitej Polskiej. Komentarz, Wolters Kluwer, Warszawa 2013, Lex'el.

Skrzydło-Niżnik I., Dobosz P., Pojęcie zrównoważonego rozwoju w systemie prawa i nauce prawa administracyjnego, w: Jednostka $w$ demokratycznym państwie prawa, red. J. Filipek, Wydawnictwo WSA, Bielsko-Biała 2003.

Szpor G., Zasada zrównoważonego rozwoju jako zagadnienie prawne, $\mathrm{w}$ : Zarzadzanie informacja przestrzenna w nowym tysiacleciu, Stowarzyszenie SILGIS Center, Katowice 1999.

Szukalski P., Czym jest solidarność międzypokoleniowa, w: Jakość życia seniorów XXI wieku z perspektywy polityki społecznej, red. D. Kałuża, P. Szukalski, Wydawnictwo Biblioteka, Łódź, dostępne pod adresem http://dspace.uni.lodz. pl:8080/xmlui/handle/11089/344.

Syryt A., Dostęp do publicznych zasobów informacyjnych a zasada zrównoważonego rozwoju, w: Jawność jej ograniczenia, t. V, Dostęp i wykorzystywanie, red. A. Piskorz-Ryń, CH Beck, Warszawa 2015.

Zimmermann J., Prawo administracyjne, Zakamycze, Warszawa 2014.

Zielona Księga ,Wobec zmian demograficznych: nowa solidarność między pokoleniami".

Agnieszka Piskorz-Ryń: The principle of sustainable development and public administration tasks regarding senior citizens from the perspective of administrative law sciences. Selected issues

\section{Summary}

It is a fact that the Polish society is getting older. We can counteract this only to a limited extent. This fact should, therefore, be taken into consideration both when designing state policies and forming administrative laws as well as when 
performing public administration tasks. The principle of sustainable development should be followed in both cases.

This would require balancing the interests of young, middle-aged and senior citizens, while taking into account the principle of sustainable development. In context of ageing society, sustainable development should envisage such formation of development processes as would permit to maintain a balance between the needs and inspiration of people in various age groups and the needs of present and future generations.

This is because sustainable development touches upon various aspects of how a society functions and needs to be of long-term nature.

Keywords: sustainability, population ageing, public administration tasks. 